\title{
Out of the mouths of babes and sucklings: lessons from early childhood asthma ${ }^{\star}$
}

\author{
M Silverman
}

The re-examination of former "truths" is at the very heart of science. In relation to the work of Roger Altounyan, for example, continued questioning of former assumptions concerning the mechanism of action of sodium cromoglycate is still producing fascinating new information about this particular agent. It is timely to re-examine our understanding of asthma and other wheezing disorders in early childhood and I am grateful to the British Thoracic Society for giving me the opportunity to review the topic. In this address I wish to re-examine the assertion that all wheezing in infancy and early childhood should be labelled "asthma" and treated accordingly. This statement belongs rather more to the realms of politics than to clinical science. It may have had a role 15 years ago in persuading doctors to treat wheezy children with bronchodilators rather than with antibiotics, but the time has come to question the lumping of all preschool lower respiratory tract wheezy illnesses under the single heading of asthma.

Over the past 10 or 12 years it has been increasingly obvious, as a result of simple clinical observations on patients and, recently, as a result of epidemiological and experimental work, that a better understanding of the nature of wheezing lower respiratory illnesses in preschool children may hold the key to a number of clinical and epidemiological puzzles.

\section{Epidemiological background}

A series of papers by Barker and colleagues has drawn our attention, in a most startling way, to the association between fetal and infant growth and development, and chronic obstructive airway disease in late adult life. The starting point was the observation that, for health districts of England and Wales, there was a strong association between infant mortality from lower respiratory illness in the 1920 s and mortality from chronic bronchitis amongst men in their $60 \mathrm{~s}$ in the $1980 \mathrm{~s}$. Careful detective work allowed the group to identify data collected by health visitors and midwives relating to growth and lower respiratory illness over the first year of life, from which it was established that low weight at birth and at 12 months of age, and a history of lower respiratory illness during the first year of life were all risk factors for chronic airway obstruction (as measured by lung function tests) at the age of $60-70$. These observations confirm both the retrospective analysis of Burrows in the $\mathrm{USA}^{2}$ and the shorter term, prospective studies of birth cohorts reported by Colley and colleagues in the UK. ${ }^{34}$

The focus of attention of these studies is early infancy and, in particular, lower respiratory illness over the first year or two of life. The nature of recurrent lower respiratory illness, characterised by wheeze and cough accompanying what appears to be a simple viral cold, is clearly a topic of great importance. In spite of the fact that $15 \%$ of infants in the first year of life, and up to $25 \%$ of under fives, attend their medical practitione with wheezing lower respiratory illnesses, and many more have milder symptoms - an indication of the public health importance of this group of disorders-neither the factors which predispose to this group of disorder nor their classification has yet been satisfactorily elucidated. The rest of this review will be devoted to an exploration of the nature of recurrent lower respiratory illness in the first years of life and its relation to atopic childhood asthma and to chronic obstructive air way disease in later life.

\section{Atopy and infant lower respiratory illness}

Most school children with asthma are atopic, with immediate skin test responses to a range of inhalant antigens and high levels of total and specific IgE. ${ }^{6}$ In the UK the most important aeroallegen associated with asthma in school children is the house dust mite antigen $\operatorname{Der} p \mathrm{I}^{6}{ }^{6}$ The importance of early exposure to this antigen was shown by the small cohort of high risk infants studied by Cogswell and colleagues in the south of England..$^{78}$ Their data showed that early exposure (in the first year of life) was critical to the subsequent development of atopic childhood asthma, and that the higher the environmental levels of $\operatorname{Der} p$ I in the first year, the earlier the onset of asthma and the more severe its manifestations. These conclusions, however, applied only to asthma at school age. In their population the odds ratio for atopic asthma at school age was not greater in those children who wheezed in the first two years of life. Nor, in retrospect, were those children who were sub- 
sequently shown to be atopic at the age of 11 more likely to have wheezed in the first two years of life. These data suggested, for the first time, that wheezing disorders of infancy and atopic childhood asthma were completely independent disorders.

The Tucson cohort, which is teaching us so much about early childhood respiratory illness, has shown even more strongly that infant wheeze and atopy are probably causally unrelated. $^{9}$ In contrast with eczema in infancy, in which there was a strong positive correlation with cord blood IgE levels, wheezing lower respiratory illness was significantly negatively correlated with cord blood IgE, a presumptive indicator of atopic predisposition. By the age of three years, wheezing had begun to show the positive correlation with IgE which would be expected for an older child with asthma. ${ }^{10}$ Our understanding of the ontogeny of atopic sensitisation is somewhat primitive, but the disparity between eczema and wheezing in infancy could be explained by the relatively earlier development of sensitisation in high risk individuals to ingested allergens compared with inhaled allergens. ${ }^{11}$ This presymptomatic period of aeroallergen sensitisation is surely a very fruitful area for further research. The events of early infancy seem to be paralleled by occupational sensitisation later in life. Models of occupational asthma might usefully be applied to the infancy situation.

There is therefore little to support any association between atopic hypersensitivity and wheezing lower respiratory illness in community based population samples of infants. It is worth nothing, however, that some hospital based populations-for instance, infants recruited because of an episode of acute viral bronchiolitis-have been reported to contain a slight excess (usually not to a major degree) of atopic children or children from atopic families, although most show no excess. ${ }^{12-14}$ It is thus possible that some atopic factor may contribute to the development of particularly severe lower respiratory tract symptoms in children with viral lower respiratory illnesses in early infancy. Since only about $1 \%$ of the population is admitted to hospital with acute viral infantile bronchiolitis, such an effect would be lost in random population studies.

\section{Bronchial hyperresponsiveness and infant lower respiratory illness}

Although groups in France and Poland had attempted to measure bronchial responsiveness to inhaled pharmacological agents using classical physiological measurement techniques, rapid progress in this technically demanding field awaited the invention of a technique for measuring lower respiratory function in a simple and repeatable manner in young infants. The squeeze technique appeared to be such a method and was quickly seized upon as the basis for measuring the response to bronchial challenge in infants. ${ }^{15-17}$ The technique is deceptively easy, and depends on the rapid application of a compressive force to the chest and abdomen by means of an inflatable jacket, the resultant forced expulsion of air being measured at the airway opening by means of a facemask and pneumotachograph system. The limitations of the technique have been well reviewed. ${ }^{18}$ Bronchial challenge with histamine or methacholine has been shown to be adequately repeatable and important information concerning the pathogenesis of lower respiratory illness in infancy has been gained using challenge methods based on the squeeze technique. Two important questions have been studied using the technique.

Firstly, is there any evidence that bronchial responsiveness differs at birth between those subjects who subsequently develop wheezing and those who do not? A large population based study in Perth has, indeed, shown that bronchial responsiveness may vary at birth, depending on parental atopy and maternal smoking. ${ }^{17}$ However, no group has yet shown that bronchial responsiveness in the newborn period is a predictor of the likelihood of subsequent wheezing, at least over the first year of life.

The second question concerns the possibility of an association between bronchial responsiveness and established recurrent lower respiratory illness in infancy. Again there are two published sets of data indicating that in infancy there is no association between the bronchial response to histamine and lower respiratory illness. ${ }^{19} 20$

Extending these observations to older children, still within the preschool group, we have again adapted innovative techniques for measuring bronchial responsiveness in that hitherto unassailable group, three year olds, and have shown that bronchial hyperresponsiveness was not associated with atopy in those with wheezing at this age. ${ }^{21}$ In fact, non-atopic children with wheezing in early childhood had a significantly greater level of bronchial responsiveness to methacholine than did atopic wheezers. It seems that bronchial hyperresponsiveness is not a feature of atopy or of wheezing disorders in very young children. Beyond the age of about seven the characteristic association between bronchial hyperresponsiveness, atopy, and asthma becomes increasingly apparent, as the prevalence of bronchial responsiveness in non-atopic groups of children diminishes to less than $5 \%$, while the level of bronchial responsiveness in atopic children persists at $30-40 \%$ of children. ${ }^{22} 23$

It seems therefore that, as with atopic hypersensitivity, bronchial hyperresponsiveness is not a feature of early childhood lower respiratory illness, with or without wheezing. Again there is powerful evidence that wheezing in early infancy has a different basis from the usual pattern of atopic childhood asthma at school age and beyond, when responsiveness is very clearly associated with atopy. ${ }^{2425}$ Perhaps there is a window of opportunity in early childhood, before atopic sensitisation leads to increased bronchial responsiveness, 
when the natural history of later atopic asthma could be modified. This, too, merits further research.

Fetal smoking, perinatal lung function, and subsequent wheezing lower respiratory illness

The hypothesis that impairment of lung function in school children or young adults who have suffered from infantile lower respiratory illness implies that illnesses in early childhood "damage the lungs" and lead to longlasting disability has only recently been questioned. Such data do not exclude the possibility that premorbid lung function could have been abnormal. Only "year zero" data can solve this problem.

Several birth cohorts were initiated in the 1980 s to try to establish whether abnormal premorbid lung function might be a risk factor for wheezing lower respiratory illness or asthma. Two studies have clearly shown that several indices of neonatal lung function differ significantly in infants who subsequently develop episodes of wheezing lower respiratory illness over the first years of life. ${ }^{2627} \mathrm{~A}$ major risk factor for abnormal lung function at birth is maternal smoking during pregnancy. ${ }^{28}$ Neonatal lung function (by the squeeze technique) was reduced to $50 \%$ of the control value in the offspring of smokers in the East Boston study. The excess risk of wheezing lower respiratory illness due to maternal smoking during pregnancy seemed to be operating through an effect on lung mechanics at birth; exposure to tobacco smoke postnatally had no additional effect, ${ }^{27}$ confirming the observations on a much larger UK birth cohort that fetal smoke exposure may be a greater risk factor than postnatal passive smoking. ${ }^{29}$ Late fetal life seems to be a critical time, since cessation of smoking earlier in pregnancy reduces the morbidity in infancy. ${ }^{30}$ Fetal pulmonary development, and its disturbance by perturbations of the fetal environment, may explain the curious observation by the East Boston group that fetal smoke exposure led to a significant reduction in neonatal lung function only in girls, despite their finding that, as expected, more boys than girls developed wheezing lower respiratory illness. This gender specific fetal response is another potentially fruitful area for study at a time of increasing awareness of environmental pollution.

We have gathered some intriguing information from the study of a cohort of low birth weight babies to suggest that, although over the first year of life remodelling of the lung may take place after perinatal insults and fetal growth disturbance, from the age of one to nine there is a remarkable degree of tracking of lung function. ${ }^{31}$ This implies that airway size, lung elasticity, and the other factors which underlie lung mechanics may be determined for life during fetal development and over the first few months of postnatal life.

It will be important to quantitate the contribution of premorbid lung function to wheezing disorders of infancy. This might enable us to say with more certainty that the link between infant lung disease and diminished lung function in early and late adult life is predetermined by fetal lung development.

\section{Clinical observations}

Attitudes towards wheezing lower respiratory illness in infancy have come full circle over the last 30 years. It is a measure of the mind set which was induced in the 1970s that the very important observations of Selander ${ }^{32}$ and Fry $^{33}$ had been largely forgotten. They had clearly shown that episodes of wheeze in young infants were temporally closely related to epidemics of viral respiratory infection in the population at large, and that infants with what appeared to be characteristic episodic viral wheeze did not turn into childhood asthmatics. In Selander's carefully followed group of wheezy infants from a small town in Sweden, almost all had completely outgrown their symptoms between the ages of six and 11 years. Although using the refined techniques of molecular biology with a high detection rate, recent studies into the viral aetiology of exacerbations of asthma ${ }^{34}$ have not materially improved on the pioneering observations of Horn et $a l^{35}$ again performed in a general practice setting, who showed that viral infections, especially rhinovirus, are commonly associated with episodes of wheeze.

A number of groups have confirmed the excellent medium term prognosis for infants with recurrent wheezing lower respiratory illness in the first two years of life. ${ }^{736-38}$ But what of the longer term prognosis? Colley, following up a 1948 birth cohort, and Henderson and colleagues have shown an association between lower respiratory illnesses in the first two years of life and a reduction in spirometric lung function in early adult life, independently of atopic sensitisation or of the presence of asthma. ${ }^{39} 40$

Are we really to believe that, leaving aside such factors as smoking and adverse social conditions, diminished lung function and excess cough are not simply the result of lung damage caused by lower respiratory illnesses in the first two years of life, but that the risk may extend back to events in fetal life? What about bronchiolitis? Surely acute severe bronchiolitis in infancy, caused in epidemics by the respiratory syncytial virus, is the clearest example of an illness in which lung damage leads to persistent problems? Let us examine this common claim in a little more detail.

It is true that over $75 \%$ of infants hospitalised for acute viral bronchiolitis in the first four months of life develop subsequent episodic wheeze with viral infections. Arguments have raged concerning the contribution of atopy to the syndrome but, if any, the contribution is very small. ${ }^{12}$ The overwhelming outcome, as for children with recurrent episodic viral wheeze who do not happen to be born just before the winter 
bronchiolitis season, is that symptoms improve as the years go by so that by middle childhood there is little to show for the initial illness. ${ }^{41}$

\section{Conclusion}

Many vital bits of information are missing. The full natural history of wheezing disorders in childhood awaits the completion of some of the detailed prospective cohort studies which are now ongoing. By chance and good detective work we have a series of overlapping longitudinal studies, each relying on different types of evidence collected in different ways and for different purposes, from which a reasonable hypothesis can be drawn. Data from Tucson, East Boston, Perth, and our

Features of the major wheezing disorders of childhood

\begin{tabular}{|c|c|c|}
\hline & $\begin{array}{l}\text { Recurrent wheezy LRI } \\
\text { in preschool children }\end{array}$ & $\begin{array}{l}\text { Asthma in } \\
\text { school children }\end{array}$ \\
\hline Pattern & Episodic & $\begin{array}{l}\text { Interval } \\
\text { symptoms + episodic }\end{array}$ \\
\hline $\begin{array}{l}\text { Peak prevalence } \\
\text { Aetiology }\end{array}$ & $\begin{array}{l}6-36 \text { months } \\
\text { Viral infection }\end{array}$ & $\begin{array}{l}5-10 \text { years } \\
\text { Atopic sensitivity ( }+ \text { viral } \\
\text { episodes) }\end{array}$ \\
\hline $\begin{array}{l}\text { Bronchial responsiveness } \\
\text { Prognosis }\end{array}$ & Normal & Increased \\
\hline Child/young adult & $\begin{array}{l}\text { Symptoms largely confined } \\
\text { to preschool era; minor } \\
\text { anomalies in early adult } \\
\text { life }\end{array}$ & Persistent \\
\hline Later life & Associated with COPD & No relation to COPD \\
\hline
\end{tabular}

LRI-lower respiratory illness; COPD—chronic obstructive pulmonary disease.
Population point prevalence

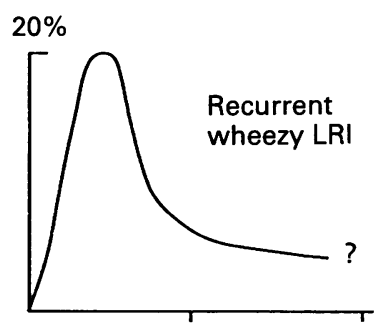

Distribution of affected individuals in the whole population
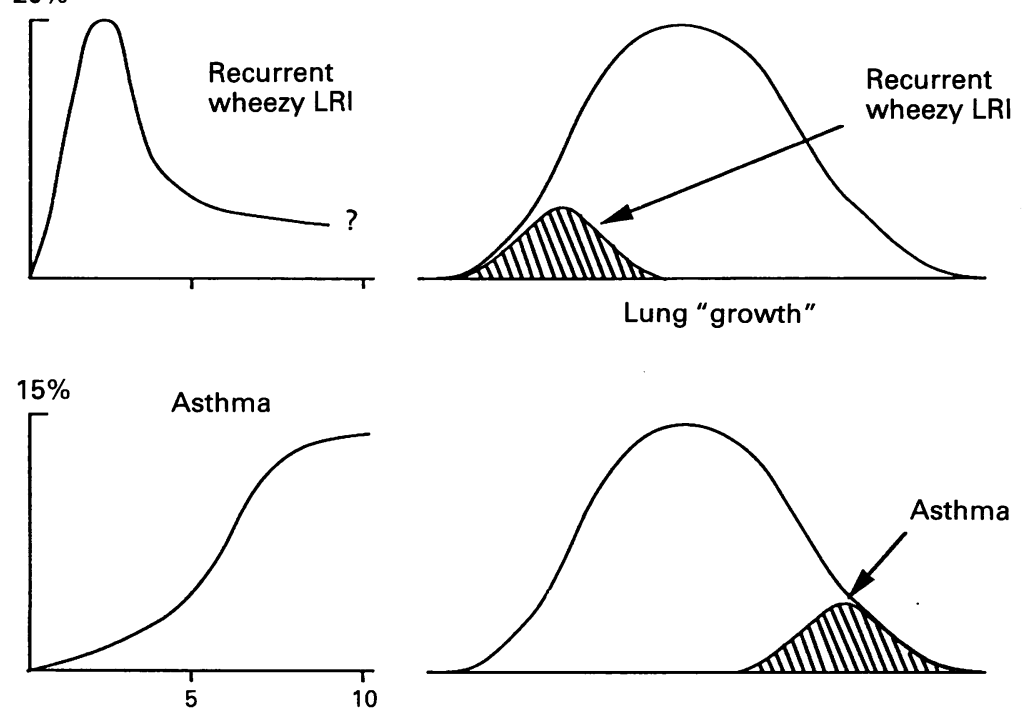

Age (years)
Atopic status $(\lg E)$
Lung "growth"

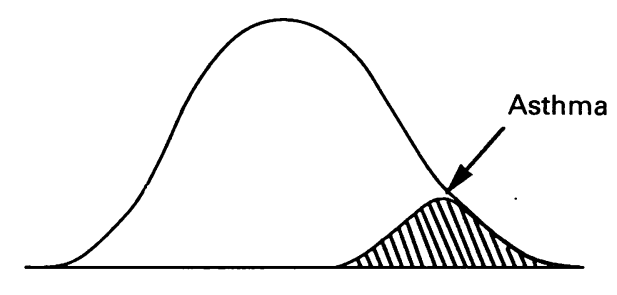

Changing prevalence of recurrent wheezy lower respiratory illness (LRI) and atopic asthma in childhood. The two distribution curves suggest the major recognisable factors which determine the distribution of affected individuals. For wheezing LRI an additional "viral factor" is needed; for asthma bronchial responsiveness in response to aeroallergen sensitisation is perhaps the necessary factor. own studies of full term and low birth weight babies ${ }^{42}$ have indicated several premorbid risk factors for recurrent lower respiratory illness in infancy: maternal smoking during pregnancy, a previous history of maternal wheeze, prematurity (or low birth weight), and reduced lung function in the neonatal period. Bronchial responsiveness at birth is not a risk factor. The series of UK national birth cohorts, starting in 1946, together with a number of other smaller surveys of select groups, have shown that lower respiratory illness under the age of two is a risk factor for cough and reduced lung function in adolescents and early adult life. Finally, the lifelong data recently unearthed by Barker and colleagues have linked fetal growth (size at birth) and lower respiratory illness in the first year of life, with increased morbidity and mortality from chronic obstructive pulmonary disease in men in their $60 \mathrm{~s}$.

How does this relate to asthma? The differences between a common pattern of episodic wheeze in early life and atopic school child asthma are so striking (table) that one can only conclude that the two disorders are totally independent. The fact that they were lumped as a single disorder is testament to the arrogance of hospital doctors and to the lack of respect afforded, until fairly recently, to clinical epidemiologists and other health professionals working in the community at large. The major differences in natural history and aetiology are illustrated in the figure.

For too long paediatricians have tended to practice "me too" medicine. The idea that children were little adults, at least in respect of their asthma, has been prevalent. The fact that babies did not appear to respond very well to bronchodilators was ascribed to our inability to administer the drugs, rather than to a possible difference in the mechanism of wheezing. In the condition of acute episodic viral lower respiratory illness of infants and toddlers, we have a distinct disorder! ${ }^{43}$ Not only is the disease of enormous public health importance, affecting a large proportion of infants at some stage in their preschool life and comprising about $20 \%$ of all acute admissions to paediatric wards, but in it are the seeds of chronic obstructive pulmonary disease-that frustrating disorder of later life. We need better epidemiological studies with clearly focused questions, starting at the real "time zero": conception. These should be backed up by histopathological data obtained by bronchoalveolar lavage, perhaps during anaesthesia or incidental surgery. The ontogeny of host defences and, in particular, the immune response to virus infections and to aeroallergens, is surely a topic which demands very much more intensive research. ${ }^{44}$ Finally, some of the big questions can only be resolved with a better understanding of the factors which disturb fetal lung growth and development.

The ideas on which this article is based are the result of many years of fruitful discussion with my colleague Dr Nicola Wilson. 
1 Barker DJP. Fetal and neonatal origins of adult disease. London: BMJ, 1992.

2 Burrows B, Knudson RJ, Lebowitz MD. Relationship of childhood respiratory illness to adult obstructive airway disease. Am Rev Respir Dis 1977;115:700-51.

3 Colley JRT, Douglas JWB, Reid DD. Respiratory disease in young adults: influence of early childhood lower respiratory illness, social class, air pollution and smoking. BMF 1973;3:195-8.

4 Mann SL, Wadsworth MEJ, Colley JRT. Accumulation of factors influencing respiratory illness in members of a national birth cohort and their offspring. $\mathcal{F}$ Epidemiol Community Health 1992;46:286-92.

5 Strachan DP. The prevalence and natural history of wheezing in early childhood. f $R$ Coll Gen Pract 1985; 35:182-4.

6 Warner JA. Environmental changes and asthma control in paediatrics. Paediatr Respir Med 1993;1:9-13.

7 Sporik R, Holgate ST, Cogswell JJ. Natural history of asthma in childhood-a birth cohort study. Arch Dis Child 1991;66:1050-3.

8 Sporik R, Holgate ST, Platts-Mills TAE, Cogswell J. Exposure to house dust mite allergen (Der $p$ I) and the development of asthma in childhood. $N$ Engl $\mathcal{F}$ Med 1990;323:502-7.

9 Halonen M, Stern D, Taussig LM, Wright A, Ray CG, Martinez FD. The predictive relationship between serum IgE levels at birth and subsequent incidences of lower respiratory illnesses and eczema in infants. $A m$ Rev Respir Dis 1992;146:866-70.

10 Halonen M, Stern D, Holberg C, Taussig LM, Ray CG, Wright $\mathrm{A}$, et al. The changing relationship of lower respiratory illness (LRI) incidence in the first three years of life to umbilical cord serum IgE levels. Am Rev Respir Dis 1993;147:(Suppl):A15.

11 Van Asperen PP, Kemp AS. The natural history of IgE sensitisation and atopic disease in early childhood. Acta Paediatr Scand 1989;78:239-45.

12 Mok JU, Simpson H. Symptoms, atopy and bronchia reactivity after lower respiratory infection in infancy. Arch Dis Child 1984;59:299-305.

13 Carlsen K-H, Larsen S, Bjerve O, Leegaard J Acute bronchiolitis: predisposing factors and characterisation of infants at risk. Pediatr Pulmonol 1987;3 153-60.

14 Murray M, Webb MSC, O'Callaghan C, Swarbrick AS Milner AD. Respiratory status and allergy after bronchiolitis. Arch Dis Child 1992;67:482-7.

15 Prendiville A, Green S, Silverman M. Bronchial responsiveness to histamine in wheezy infants. Thorax 1987; 42:92-9.

16 Tepper R. Airway reactivity in infants: a positive response to methacholine and metaproterenol. f Appl Physiol 1987;62:1155-9.

17 Young S, Le Souef PN, Geelhoed GC, Stick SM, Turner KS, Landau LI. The influence of a family history of asthma and parental smoking on airway responsiveness in early infancy. $N$ Engl $\mathcal{F}$ Med 1991;324:1168-73.

18 American Thoracic Society/European Respiratory Society. Respiratory mechanics in infants: physiologic evaluation in health and disease. Am Rev Respir Dis 1993;147: 474-96.

19 Stick SM, Arnott J, Turner DJ, Young S, Landau LI, Le Souef PN. Bronchial responsiveness and lung function in recurrently wheezy infants. Am Rev Respir Dis 1991 144:1012-5.

20 Clarke J R, Reese A, Silverman M. Bronchial responsiveness and lung function in infants with lower respiratory tract illness over the first 6 months of life. Arch Dis Child 1992;67:1454-8.

21 Wilson NM, Phagoo SB, Silverman M. Atopy, bronchia responsiveness and symptoms in wheezy 3 year olds. Arch Dis Child 1992;67:491-5.

22 Crane J, O'Donnell TV, Prior IA, Waite DA. The relationship between atopy, bronchial hyperresponsiveness and family history of asthma: a cross sectional study of migrant Tokelauan children in New Zealand. $f$ Allergy Clin Immunol 1989;84:768-72.

23 Adachi $Y$, Murakami G, Matsuno $M$, Adachi $Y S$ Kayahara $M$, Okada $\mathrm{T}$, et al. Longitudinal study of
bronchial hyperreactivity in preschool children with bronchial asthma. Ann Allergy 1992;68:261-6.

24 Sears MR, Burrows B, Flannery EM, Herbison GP, Hewitt CJ, Holdaway MD. Relation between airway responsiveness and serum IgE in children with asthm and in apparently normal children. $N$ Engl $f$ Med 1991; 325:1067-71.

25 Salome CM, Peat JK, Britton WJ, Woolcock AJ Bronchial hyper-responsiveness in two populations of Australian school children. I. Relation to respiratory symptoms and diagnosed asthma. Clin Allergy 1987;17: 271-81.

26 Martinez FD, Morgan WJ, Wright AL, Holberg CJ, Taussig LM. Diminished lung function as a predisposing factor for wheezing respiratory illness in infants. $N$ Engl f Med 1988;319:1112-7.

27 Tager IB, Hanrahan JP, Tostesan TD, Castile RG, Brown RW, Weiss ST, et al. Lung function, pre- and post-natal smoke exposure, and wheezing in the first year of life. Am Rev Respir Dis 1993;147:811-7.

28 Hanrahan JP, Tager IB, Segal MR, Tosteson TD, Castile RG, Van Vunakis $H$, et al. The effect of maternal smoking during pregnancy on early infant lung function. $\mathrm{Am}$ Rev Respir Dis 1992;145:1129-35.

29 Taylor B, Wadsworth J. Maternal smoking during pregnancy and lower respiratory tract illness in early life. Arch Dis Child 1987;62:786-91.

30 Ahlsten G, Cnattisgius S, Lindmark G. Cessation of smoking during pregnancy improves fetal growth and reduces infant morbidity in the neonatal period. Acto Paediatr Scand 1993;82:177-81.

31 Chan K N, Wong Y C, Silverman M. Relationship between infant lung mechanics and childhood lung function in children of very low birthweight. Pediat Pulmonol 1990;8:74-81.

32 Selander P. Asthmatic symptoms in the first year of life Acta Paediatr Scand 1960;49:265-9.

33 Fry J. "Acute wheezy chests". Clinical patterns and natural history. BMF 1961;1:227-32.

34 Pattemore PK, Bardin PG. Viruses as precipitants of asthma symptoms. 1. Epidemiology. Clin Exp Allergy 1992;22:325-36.

35 Horn MEC, Gregg I. Brain EA, Inglis JM, Yealland SI, Taylor P. Respiratory viral infection and wheezy bronchitis in childhood. Thorax 1979;34:23-8.

36 Foucard T, Sjoberg O. A prospective 12-year follow up study of children with wheezy bronchitis. Acta Paediat Scand 1984;73:577-83.

37 Park EJ, Golding J, Carswell F, Stewart-Brown S. Preschool wheezing and prognosis at 10. Arch Dis Child 1986;61:642-6.

38 Poder G, Nagy A, Kelemen J, Mezei G. Prognostic dat for the second follow-up in childhood wheezy bronchitis. Acta Paediatr Hung 1992;32:43-52.

39 Britten N, Davies JMC, Colley JRT. Early respiratory experience and subsequent cough and peak expiratory flow rate in 36 year old men and women. BMF 1987 294:1317-20.

40 Strope GL, Stewart PW, Henderson FW, Inine SS, Stedman HC, Henry MM. Lung function in school-age children who had mild lower respiratory illnesses in early childhood. Am Rev Respir Dis 1991;144:655-62.

41 Pullan CR, Hey EN. Wheezing, asthma and pulmonary dysfunction 10 years after infection with respiratory syncitial virus in infancy. BMF 1982;284:1665-9.

42 Chan $K$ N, Elliman A, Bryan E M, Silverman $M$ Respiratory symptoms in children of low birthweight. Arch Dis Child 1989;64:1294-304.

43 Wilson N M. Wheezy bronchitis revisited. Arch Dis Child 1989;64:1194-9.

44 Trigg CJ, Davies RJ. Infection, asthma and bronchial hyperresponsiveness. Respir Med 1993;87:165-7. 